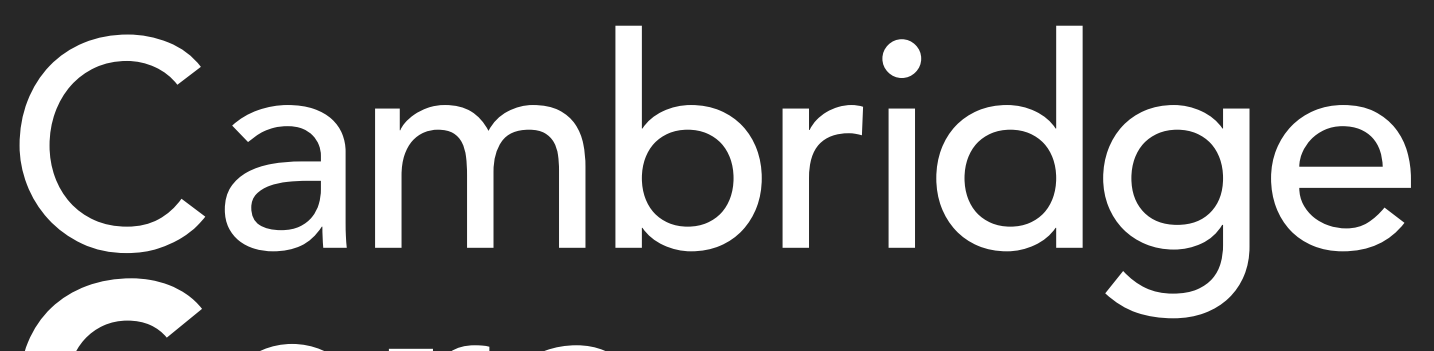

\title{
The new
}

home of

academic

content

cambridge.org/core

Cambridge Core 


\section{Politics \& International Relations \\ Books and Journals from Cambridge University Press}

The politics list at Cambridge is one of unparalleled quality and range.

Our books list routinely tops surveys of political scientists for the calibre of its output, which includes field-defining series such as Cambridge Studies in Comparative Politics, Cambridge Studies in International Relations and Cambridge Texts in the History of Political Thought.

American Political Science Review and International Organization are widely recognised as the leading generalist journals in political science and international relations, while the likes of British Journal of Political Science and World Politics remain essential reading for researchers worldwide.

For students and scholars across the breadth of political enquiry, Cambridge is the resource of choice.

For further details visit:

cambridge.org/core-politics-and-IR

\section{Cambridge}




\section{Notes for Contributors}

All manuscripts should be submitted via our online system, Editorial Manager, at: http://bjpols/edmgr.com

For the Notes for Contributors please see online at:

http://journals.cambridge.org/images/fileUpload/documents/jps_ifc.pdf

\section{COPYING}

This journal is registered with the Copyright Clearance Center, 222 Rosewood Drive, Danvers, Mass. 01923, USA. Organizations in the USA which are also registered with the C.C.C. may therefore copy material (beyond the limits permitted by sections 107 and 108 of US copyright law) subject to payment to C.C.C. of the per copy fee of $\$ 12.00$. This consent does not extend to multiple copying for promotional or commercial purposes Code 0007-1234/2019 \$12.00.

Organizations authorized by the Copyright Licensing Agency may also copy material subject to the usual conditions.

\section{ABSTRACTING AND INDEXING}

The journal is listed in the major relevant abstracting and indexing services worldwide, including ABC Political Science, Automated Subject Citation Alert, America History and Life, Applied Social Science Index and Abstracts, Current Contents, Historical Abstracts, International Political Science Abstracts, Sage Public Administration Abstracts, Social Sciences Index, Studies on Women Abstracts. 


\section{British Journal of Political Science}

\section{ARTICLES}

401 Luke N. Condra, Mohammad Isaqzadeh and Sera Linardi

Clerics and Scriptures: Experimentally Disentangling the Influence of Religious Authority in Afghanistan

421 John F. McCauley and Daniel N. Posner

The Political Sources of Religious Identification: Evidence from the Burkina Faso-Côte d'Ivoire Border

443 Jane Green and Will Jennings

Party Reputations and Policy Priorities: How Issue Ownership Shapes Executive and Legislative Agendas

467 Zachary Peskowitz

Ideological Signaling and Incumbency Advantage

491 Bjørn Høyland, Sara B. Hobolt and Simon Hix

Career Ambitions and Legislative Participation: The Moderating Effect of Electoral Institutions

513 J. Scott Matthews

Issue Priming Revisited: Susceptible Voters and Detectable Effects

533 Konstantin Vössing and Till Weber

Information Behavior and Political Preferences

557 Adrián Lucardi

The Effect of District Magnitude on Electoral Outcomes: Evidence from Two Natural Experiments in Argentina

\section{Stan Hok-Wui Wong}

Gerrymandering in Electoral Autocracies: Evidence from Hong Kong

611 Haifeng Huang and Yao-Yuan Yeh

Information from Abroad: Foreign Media, Selective Exposure and Political Support in China

637 Jennifer Hadden and Lorien Jasny

The Power of Peers: How Transnational Advocacy Networks Shape NGO Strategies on Climate Change

661 Malcolm Fairbrother

When Will People Pay to Pollute? Environmental Taxes, Political Trust and Experimental Evidence from Britain

683 David J. Bailey and Saori Shibata

Austerity and Anti-Austerity: The Political Economy of Refusal in 'Low-Resistance' Models of Capitalism

711 Jan Pierskalla, Alexander De Juan and Max Montgomery

The Territorial Expansion of the Colonial State: Evidence from German East Africa 1890-1909

739 Benjamin T. Jones and Eleonora Mattiacci

A Manifesto, in 140 Characters or Fewer: Social Media as a Tool of Rebel Diplomacy

763 Lisa Herzog and Bernardo Zacka

Fieldwork in Political Theory: Five Arguments for an Ethnographic Sensibility

\section{NOTES AND COMMENTS}

785 David Fortunato, Lanny W. Martin and Georg Vanberg

Committee Chairs and Legislative Review in Parliamentary Democracies 